\title{
Carboxy Terminal of $\beta$-Amyloid Deposits in Aged Human, Canine, and Polar Bear Brains
}

\author{
TINA L. TEKIRIAN,* GREGORY M. COLE, $\dagger$ MICHAEL J. RUSSELL, $\ddagger$ FUSHEN YANG, $\dagger$ \\ DAVID R. WEKSTEIN, ${ }^{*}$ ELA PATEL,* DAVID A. SNOWDON,* WILLIAM R. MARKESBERY* AND \\ JAMES W. GEDDES*1
}

\author{
*Alzheimer's Disease Research Center, Sanders-Brown Center on Aging, 209 Sanders-Brown Building, University of \\ Kentucky, Lexington, $K Y 40536$ \\ †Geriatrics, Sepulveda VA Hospital, Sepulveda, CA 91343 \\ $\ddagger$ Anesthesiology, School of Medicine, University of California, Davis, CA 95616
}

\author{
Received 17 April 1995; Revised 10 July 1995; Accepted 13 October 1995
}

\begin{abstract}
TEKIRIAN, T. L., G. M. COLE, M. J. RUSSELL, F. YANG, D. R. WEKSTEIN, E. PATEL, D. A. SNOWDON, W. R. MARKESBERY AND J. W. GEDDES. Carboxy terminal of $\beta$-amyloid deposits in human, canine, and polar bear brains. NEUROBIOL AGING 17(2) 249-257, 1996.-Immunocytochemistry, using antibodies specific for different carboxy termini of $\beta$-amyloid, $A \beta 40$ and $A \beta 42(43)$, was used to compare $\beta$-amyloid deposits in aged animal models to nondemented and demented Alzheimer's disease human cases. Aged beagle dogs exhibit diffuse plaques in the absence of neurofibrillary pathology and the aged polar bear brains contain diffuse plaques and PHF-1-positive neurofibrillary tangles. The brains of nondemented human subjects displayed abundant diffuse plaques, whereas the AD cases had both diffuse and mature (cored) neuritic plaques. Diffuse plaques were positively immunostained with an antibody against $A \beta 42(43)$ in all examined species, whereas $A \beta 40$ immunopositive mature plaques were observed only in the human brain. Anti-Aß40 strongly immunolabeled cerebrovascular $\beta$-amyloid deposits in each of the species examined, although some deposits in the polar bear brain were preferentially labeled with anti-A $342(43)$. $\beta$-Amyloid deposition was evident in the outer molecular layer of the dentate gyrus in the aged dog, polar bear, and human. Within this layer, $A \beta 42$ was present as diffuse deposits, although these deposits were morphologically distinct in each of the examined animal models. In dogs, $A \beta 42$ was cloud-like in nature; the polar bear demonstrated a more aggregated type of deposition, and the nondemented human displayed well-defined deposits. Alzheimer's disease cases were most frequently marked by neuritic plaques in this region. Taken together, the data indicate that $\beta$-amyloid deposition in aged mammals is similar to the earliest stages observed in human brain. In each species, $A \beta 42(43)$ is the initially deposited isoform in diffuse plaques.
\end{abstract}

B-Amyloid Dogs Polar bears Humans

$\beta$-AMYLOID $(A \beta)$ is often associated with two Alzheimer disease-related lesions: diffuse and neuritic senile plaques, and cerebrovascular angiopathy (CVA) $(6,41)$. These lesions are also present in the brain of aged mammals including dogs, bears, and primates $(7,23,33)$. In this study, antibodies specific for the carboxy terminal of $A \beta$ were used to compare the deposits present in the aged mammals with those observed in Alzheimer's disease (AD) and in nondemented elderly individuals.

There are numerous neuritic plaques in the $\mathrm{AD}$ cortex. These plaques are also present, albeit to a lesser extent, in normal elderly individuals (44). Such plaques can be subclassified as immature or mature. Immature neuritic plaques contain $A \beta$ fibrils intermixed with swollen neurites in a well-defined spherical plaque (50). Mature, dense-cored plaques are surrounded by a wreath of dystrophic neurites; these entities are further defined by the presence of apolipoprotein E (APOE) as well as reactive astrocytes $(18,30)$. Diffuse plaques are amorphous in nature and not associated with swollen neurites or glial components (32). In Down syndrome, diffuse plaques precede the appearance of neuritic plaques and neurofibrillary tangles (22). Diffuse plaques might be precursors of neuritic plaque formation (22). However, each subtype may be formed through independent mechanisms $(9,38)$. In addition to plaques, $A \beta$ is often deposited in the leptomeninges, particularly within the tunica media of small arteries and veins (21). Whether cerebrovascular amyloidosis (CVA) is a condition that coexists with $\mathrm{AD}$ or is a separate entity, in and of itself, is under debate (47).

$A \beta$, a 39-43 amino acid peptide, is proteolytically derived from a $\beta$-amyloid precursor protein ( $\beta \mathrm{APP})$, which has a large extracellular $\mathrm{N}$-terminus, a single membrane spanning region, and a short C-terminus (35). In $\mathrm{AD}$, there is heterogeneity of the $\mathrm{A} \beta$ amino and carboxyl termini. At the amino terminus, $A \beta$ can begin at the first amino terminal residue $\left(A \beta_{N 1}\right)$ or at a modified third amino acid where glutamate is converted to pyroglutamate, $\mathrm{A} \beta_{\mathrm{N} 3(\mathrm{pE})}(25,34)$. At the carboxyl terminus, conflicting reports have suggested that $A \beta 42(24,31)$ or $A \beta 40$ is the major species (25) present in parenchymal $A \beta$ deposits. Biochemical studies suggest that $A \beta 40$ predominates in cerebrovascular amyloid (24,

${ }^{1}$ To whom requests for reprints should be addressed. 
TABLE 1

HUMAN, POLAR BEAR, AND BEAGLE DOG CASES EXAMINED

\begin{tabular}{llllll}
\hline Case & Species & Age & Sex & MMSE & \\
\hline H1 & Human & 84 & F & $26 / 30$ & Nondemented, abundant diffuse plaques, CVA \\
H2 & Human & 95 & F & $30 / 30$ & Nondemented, abundant diffuse plaques, CVA \\
H3 & Human & 78 & F & $14 / 30$ & Alzheimer's disease, CVA \\
H4 & Human & 77 & M & NA & Alzheimer's disease, CVA \\
H5 & Human & 71 & F & $15 / 30$ & Alzheimer's disease, no CVA \\
H6 & Human & 78 & F & NA & Alzheimer's disease, CVA \\
PB1 & Polar Bear & 35 & M & & Diffuse plaques and NFTs \\
PB2 & Polar Bear & 36 & F & & Diffuse plaques and NFTs, CVA \\
D1 & Beagle Dog & 14.5 & F & & Diffuse plaques, CVA \\
D2 & Beagle Dog & 16 & F & & Diffuse plaques, CVA \\
D3 & Beagle Dog & 17 & M & & Diffuse plaques, CVA \\
D4 & Beagle Dog & 14 & M & & Few diffuse plaques, CVA \\
D5 & Beagle Dog & 14 & F & & Diffuse plaques, CVA \\
\end{tabular}

Abbreviations: CVA, cerebrovascular $\beta$-amyloid deposits; MMSE, Mini-Mental examination score; NA, not available; NFTs, neurofibrillary tangles.

31). In cerebrospinal fluid, $A \beta 40$ is the major isoform (37). The secretion of $A \beta 40$ is greater than that of $A \beta 42$ in human neuroblastoma (M17) cells transfected with $\beta$ APP (43). Transfection of the neuroblastoma cells with $\beta$ APP717 mutants linked to familial $A D$ results in increased release of $A \beta 42(43)$. The significance of the various isoforms is at least twofold. Polymerization into amyloid fibrils is more rapid with 1-42 than with $1-40(15,29)$, and may be even more rapid with $3(\mathrm{pE})-42$ (34). Secondly, the $A \beta$ isoform-dependent aggregation state directly affects amyloidogenic toxicity $(5,28)$. The proximity of a number of FAD mutations to $A \beta$ suggests that aberrant $\beta A P P$ processing at the $C$ terminus and/or N-terminus could play an important role in AD (35). In sporadic AD cases, monoclonal antibodies specific for the carboxyl terminus of $A \beta 1-40$ or $1-42(43)$ demonstrate that $A \beta 42(43)$ is present in both diffuse and neuritic plaques, whereas $A \beta 40$ is found in a subset of primarily mature (cored) plaques $(14,20,52)$. Additionally, antibodies against $A \beta 42(43)$ and $A \beta 40$ immunostain CVA in meningeal vessels. In familial AD cases with the $\beta$ APP7 17 mutation ( $\mathrm{Val}$ to $\mathrm{Ile}$ ), a similar predominance of $A \beta 42(43)$ over $A \beta 40$ immunopositive plaques is observed (14). In

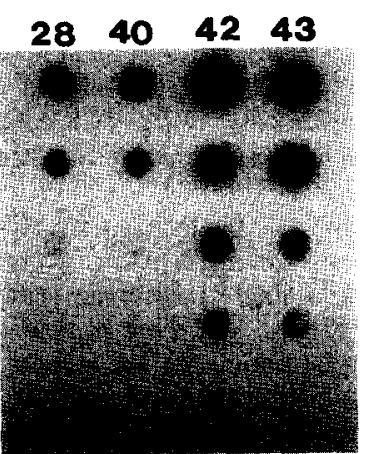

FIG. 1. A dot blot illustrating the specificity of monoclonal 7A3 made for $A \beta 42$ (43) peptide. $A \beta 1-28,1-40,1-42$, or $1-43(10 \mathrm{ng})$ was absorbed onto $0.22 \mu \mathrm{M}$ Immobilon membrane and dot blotted with serial 1:2 dilutions of $7 \mathrm{~A} 3$ ascites starting at 1:400. The ascites was produced from the same clone as the hybridoma. A $\beta 1-28$ defines background staining, because this peptide does not overlap with the $A \beta 37-42$.
Down syndrome brains, the appearance of $A \beta 42(43)$ immunostained plaques precede the appearance of $A \beta 40$-positive senile plaques (13). This has led to the suggestion that $\mathrm{AD}$ may be initiated by the deposition of $A \beta 42$ (53).

The amino acid sequence of the 43 amino acid $A \beta$ peptide is identical in dogs, polar bears, monkeys, and humans (16). Antibodies against human $A \beta$ crossreact with plaque and CVA deposits in aged dogs, bears, and primates (36). Although $\beta$-amyloid deposits and CVA have been observed in the human, aged primate (36), bear (7), and dog brain (49), the extent of AD-like pathology

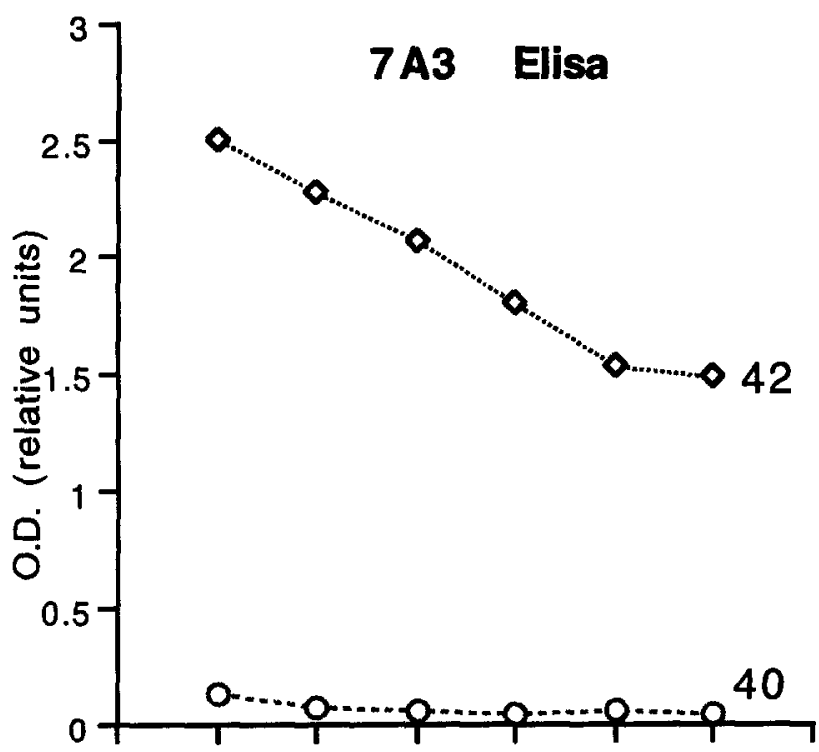

Serial 1:2 dilutions

FIG. 2. ELISA demonstrates that $7 \mathrm{~A} 3$ recognizes the $C$-terminus of $A \beta 1-$ 42 but not 1-40. Synthetic peptides $A \beta 34-40$ and $37-42$ conjugated to ovalbumin were plated at $300 \mathrm{ng}$, blocked and reacted with 1:2 serial dilutions of 7A3 hybridoma followed by detection with alkaline phosphatase conjugated antimouse IgG. 

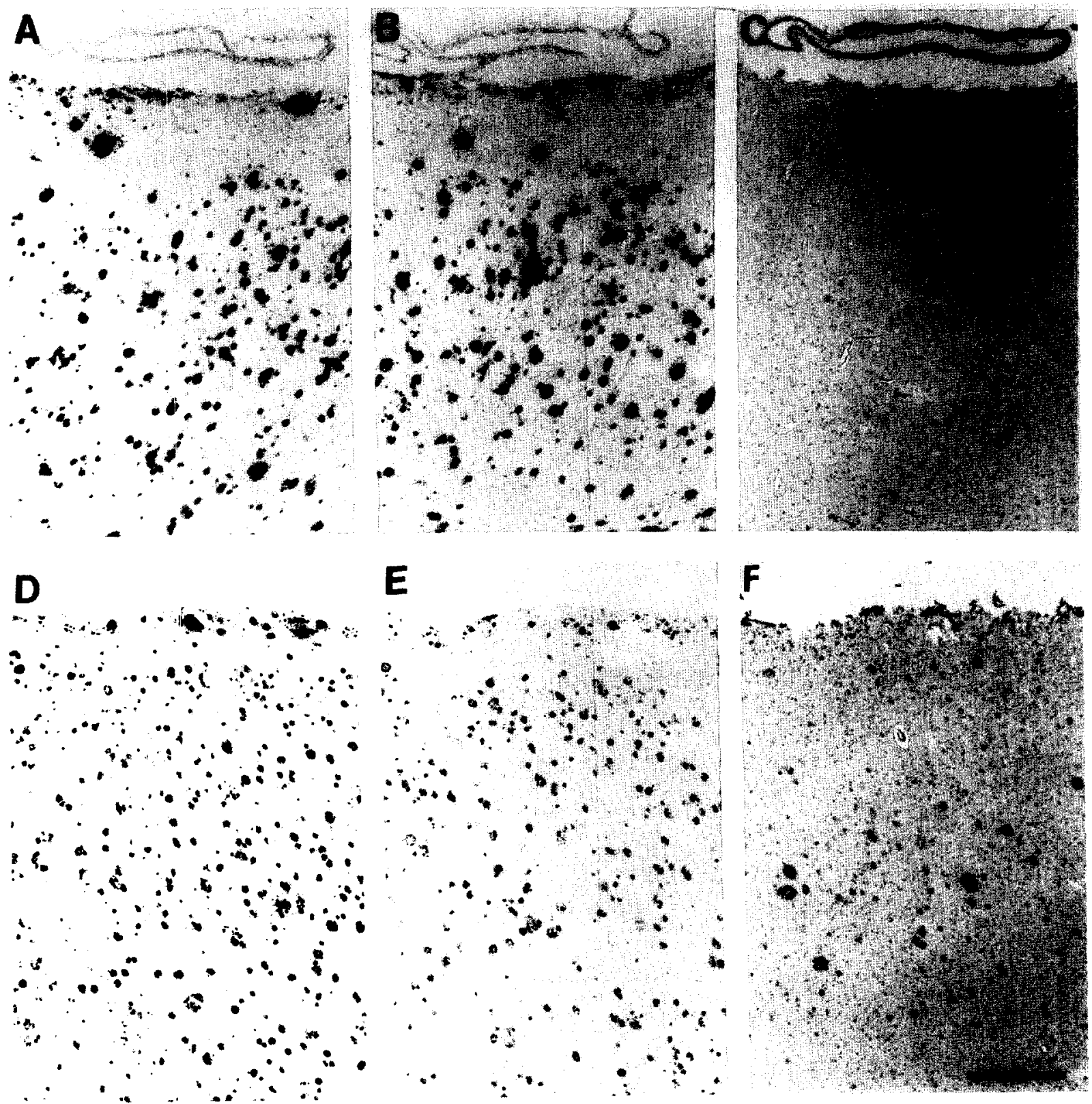

FIG. 3. Differential staining of $\beta$-amyloid deposits in human brain by $C$-terminal specific antibodies. In a nondemented 84-year-old female, in which diffuse plaques were abundant, $10 \mathrm{D} 5$ (A) and 7A3 (B) immunostained the parenchymal $\beta$-amyloid deposits in a similar fashion, but staining was rarely observed with anti-A $\beta 40$ (C). In the leptomeninges, anti-A $\beta 40$ strongly immunostained the $\beta$-amyloid deposits, whereas these were faintly labeled with 10D5 and 7A3. In a 71-year-old male with $A D$, both diffuse and neuritic plaques were strongly immunostained these were faintly labeled with 10D5 and 7A3. In a 71-year-old male with $A D$, both (D). The 7A3 antibody (anti-AB42) produced a similar in the superior temporal gyrus with the represent parahippocampal gyrus, D-F are from the superior temporal region. Scale bar $=200 \mu \mathrm{m}(\mathrm{F})$.

varies among these species. Aged dogs develop diffuse plaques and rarely exhibit neuritic plaques and neurofibrillary tangles $(8$, 33 ). Aged bears develop both neuritic (senile) plaques and neurofibrillary tangles (7). Severity of the $\beta$-amyloid deposits in the aged animals more closely resembles normal human aging than $\mathrm{AD}$.

The purpose of this study was to use antibodies specific for the $C$-terminus of $\beta$-amyloid to examine $A \beta$ deposits in aged mammals, with and without neurofibrillary pathology (beagle dog vs. polar bear). The results are compared to those obtained in the nondemented and demented (AD) human brain.
METHOD

\section{Aged Canine Tissues}

The aged beagle dog brain tissues examined in this study (Table 1) were obtained from the National Radiobiology Archives, as previously described $(8,33)$. The animals received low levels of strontium- 90 in their diet, but their longevity did not significantly differ from those of the control group. A previous study indicated a similar diffuse plaque distribution for this group and for those animals that were not exposed to radiation (33). The beagles either died of natural causes or were euthanized, due to terminal illness 


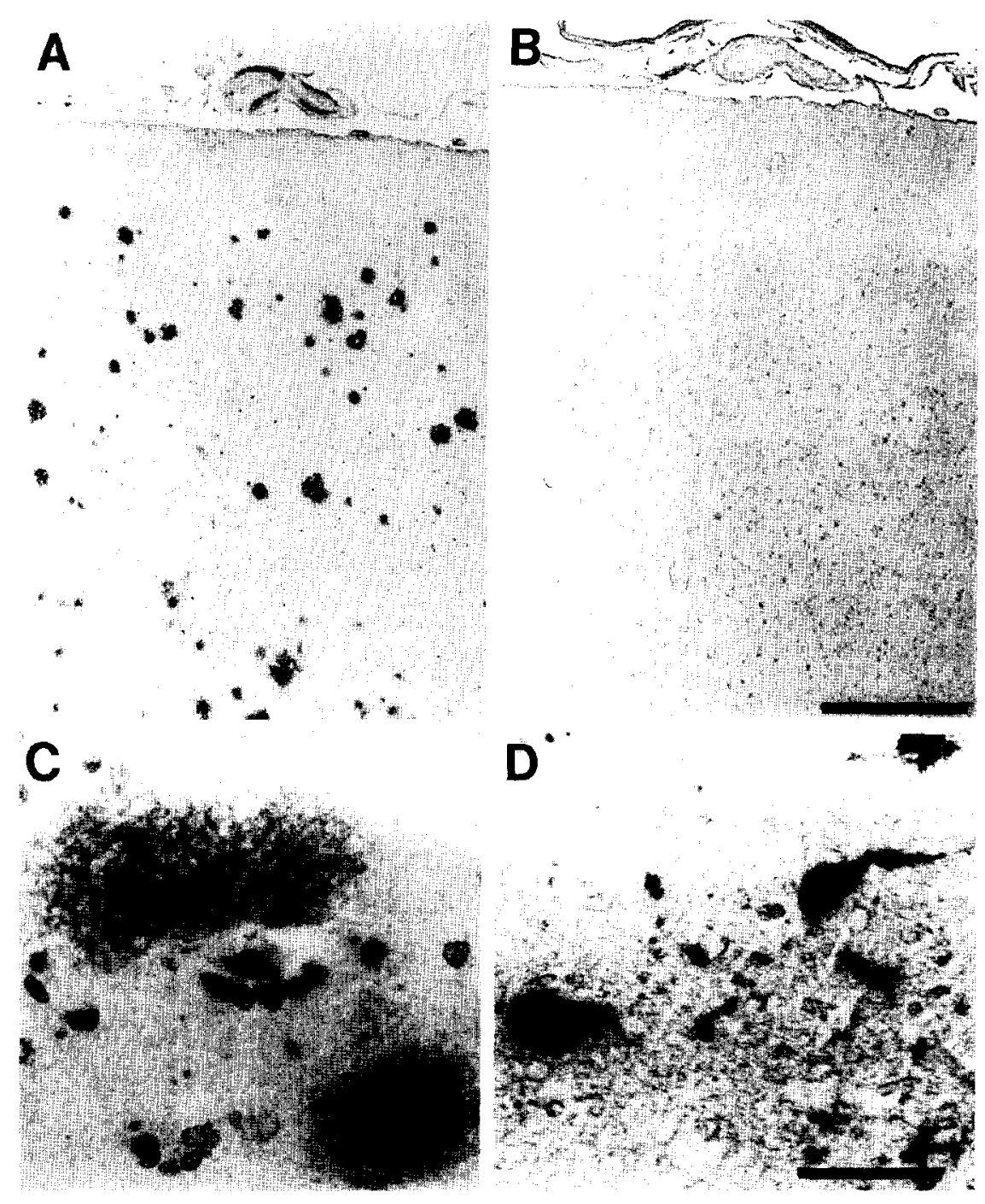

FIG. 4. $\beta$-Amyloid deposits and neurofibrillary tangles in the aged polar bear. In a 36-year-old female polar bear, diffuse plaques were abundant in frontal cortex. In addition, $A \beta$ deposits were evident in the leptomeninges. These were both strongly immunostained with $7 \mathrm{~A} 3$ (A) but not with anti- $A \beta 40$ (B). An enlarged view of a 7A3 immunostained diffuse plaque is illustrated in (C). This section was also stained with hematoxylin to indicate cell bodies, and photographed using a blue filter to increase the contrast of the $A \beta$ immunostaining over the hematoxylin. Neurofibrillary tangles were also present in the two polar bears examined, and were immunostained with the PHF-1 antibody (D). Although one tangle in this figure shows prominent staining of the apical dendrite, this was rarely observed and the tangles were not accompanied by neuropil threads. Scale bars $=200 \mu \mathrm{m}(\mathrm{B})$ and $50 \mu \mathrm{m}(\mathrm{D})$.

or chronic pain. Necropsy included thorough gross and microscopic pathologic evaluations of all major organ systems. Brain tissue samples were immersion-fixed in $10 \%$ neutral-buffered formalin. For this study, tissue was obtained from the hippocampal formation, parahippocampal gyrus, and temporal cortex, paraffinembedded, then sectioned at $10 \mu \mathrm{m}$.

\section{Aged Polar Bears}

The aged polar bears examined in this study (Table 1) were obtained from a Toledo, $\mathrm{OH}$, zoo. One bear, a 35-year-old male, was euthanized due to back injury. The second bear was also euthanized ( 36 years old, renal disease complications). At autopsy, the brains were removed and placed in $10 \%$ neutral buffered for- malin. Subsequently, hippocampal formation and temporal cortex blocks were paraffin-embedded and sectioned at $10 \mu \mathrm{m}$.

\section{Human Tissues}

Six human brains, from subjects ranging between ages 71-95, were obtained from the brain repository of the University of Kentucky Alzheimer's Disease Research Center (ADRC) (Table 1). At autopsy, brain specimens were placed in $10 \%$ buffered formalin. After fixation, the tissue was paraffin embedded and sectioned at $10 \mu \mathrm{m}$. Four of the subjects had histories of progressive dementia and neuropathologic evaluation confirmed diagnoses of Alzheimer's disease using established criteria (17). Two individuals were not demented, as determined by neuropsychological testing (Table 
A
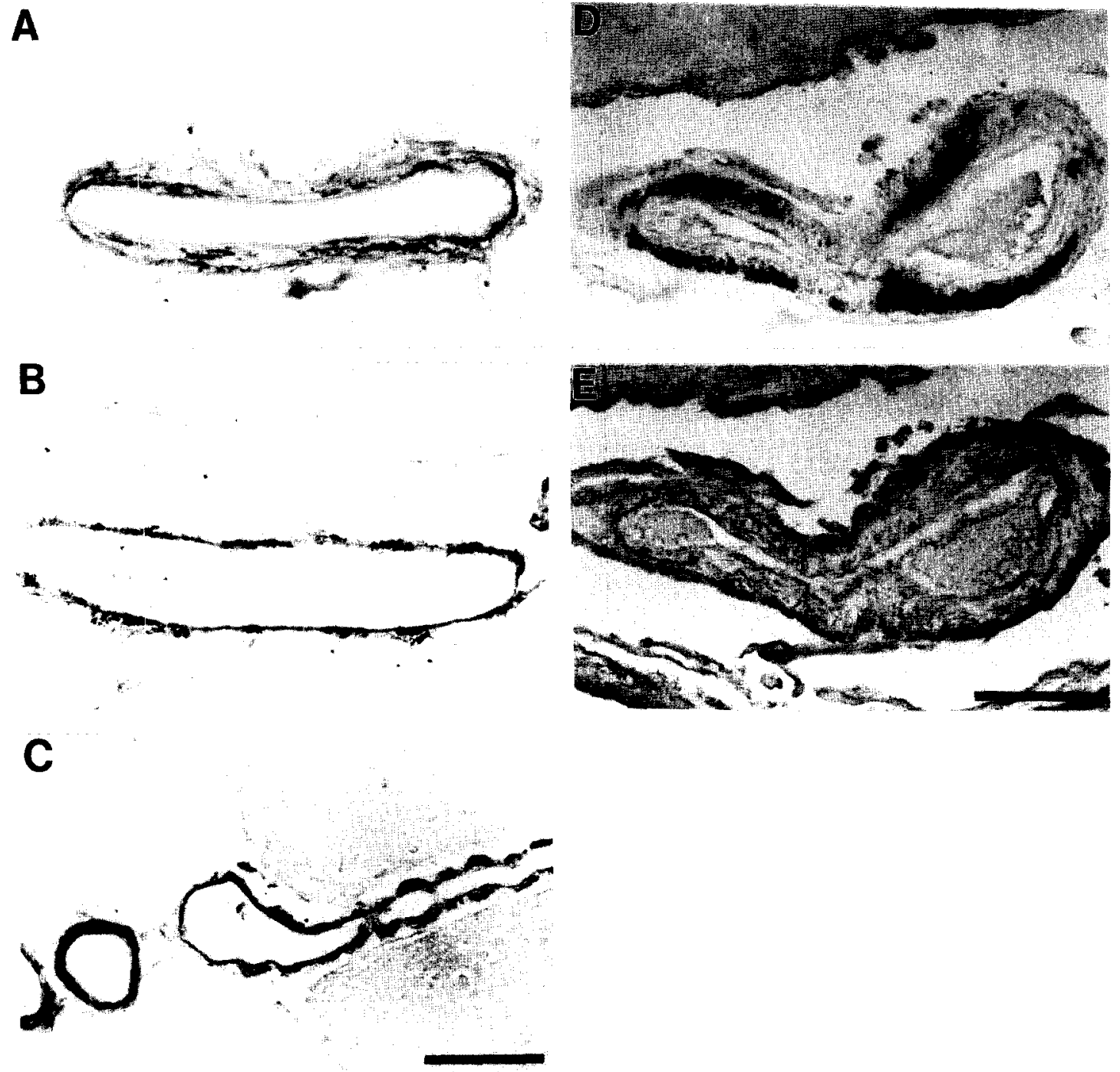

FIG. 5. Leptomeningeal $\beta$-amyloid deposits in the aged dog and polar bear. In the aged dog, leptomeningeal $A \beta$ was detected with the 7A3 (A) anti-A 340 (B) and 10D5 (C) antibodies. In an aged polar bear, one vessel was strongly labeled by 7A3 (D), whereas only nonspecific background staining was observed with anti-A $\beta 40$ (E). Scale bar $=200 \mu \mathrm{m}$.

1); however, neuropathologic evaluation revealed numerous diffuse plaques without a significant number of neurofibrillary tangles. Atherosclerosis of moderate severity was also observed in these two individuals. Areas examined included hippocampus, amygdala, as well as the superior and middle temporal cortices.

\section{Histology}

Tissue sections were deparaffinized and stained by the modified Bielschowsky method and Thioflavin-S techniques (51). For immunocytochemistry, the slides were deparaffinized, then pretreated with formic acid (19), pepsin (10 min), and $3 \% \mathrm{H}_{2} \mathrm{O}_{2}$ in $10 \%$ methanol. Sections were incubated with primary antibody overnight, at room temperature. Primary antibodies included monoclonal anti-A $\beta 42(43)(7 \mathrm{~A} 3,1: 20)$, monoclonal anti-A $\beta 1-16$ (10D5, 1:100), monoclonal PHF-1 (1:100), or polyclonal anti$\mathrm{A} \beta 40(1: 1000)$. With the exception of $7 \mathrm{~A} 3$, all of the antibodies have been completely characterized $(12,20,48,52)$. 7A3 is a monoclonal antibody generated algainst $A \beta 37-42$. The procedures that were used to produce 7A3 have been previously described with regard to the production of monoclonal antibody specific for the C-terminus of $\beta$-amyloid (52). Characterization of 7A3 is presented in the Results section.

Negative controls for immunolabeling included omission of the primary antibody and substitution of primary antibody with normal serum as well as preadsorption of each antibody with $A \beta \quad 1-40$ and $37-42$ peptide $(20 \mu \mathrm{g} / \mathrm{ml})$. Sections were incubated with the appropriate biotinylated secondary antibody (goat antirabbit IgG or horse antimouse IgG, Vector Laboratories, Burlingame, CA) followed by avidin-biotin complex (ABC Elite Kit, Vector). Color visualization was attained with diaminobenzidine (Sigma) or metal-enhanced diaminobenzidene (Pierce, Rockford, IL). Some sections were also counterstained with hematoxylin. All sections were examined and photographed on an Olympus $\mathrm{BH}-2$ microscope.

\section{RESULTS}

The 7A3 antibody was characterized using dot blot, ELISA, and preadsorption with $A \beta 37-42$ and $A \beta 1-40$. The dot blot (Fig. 

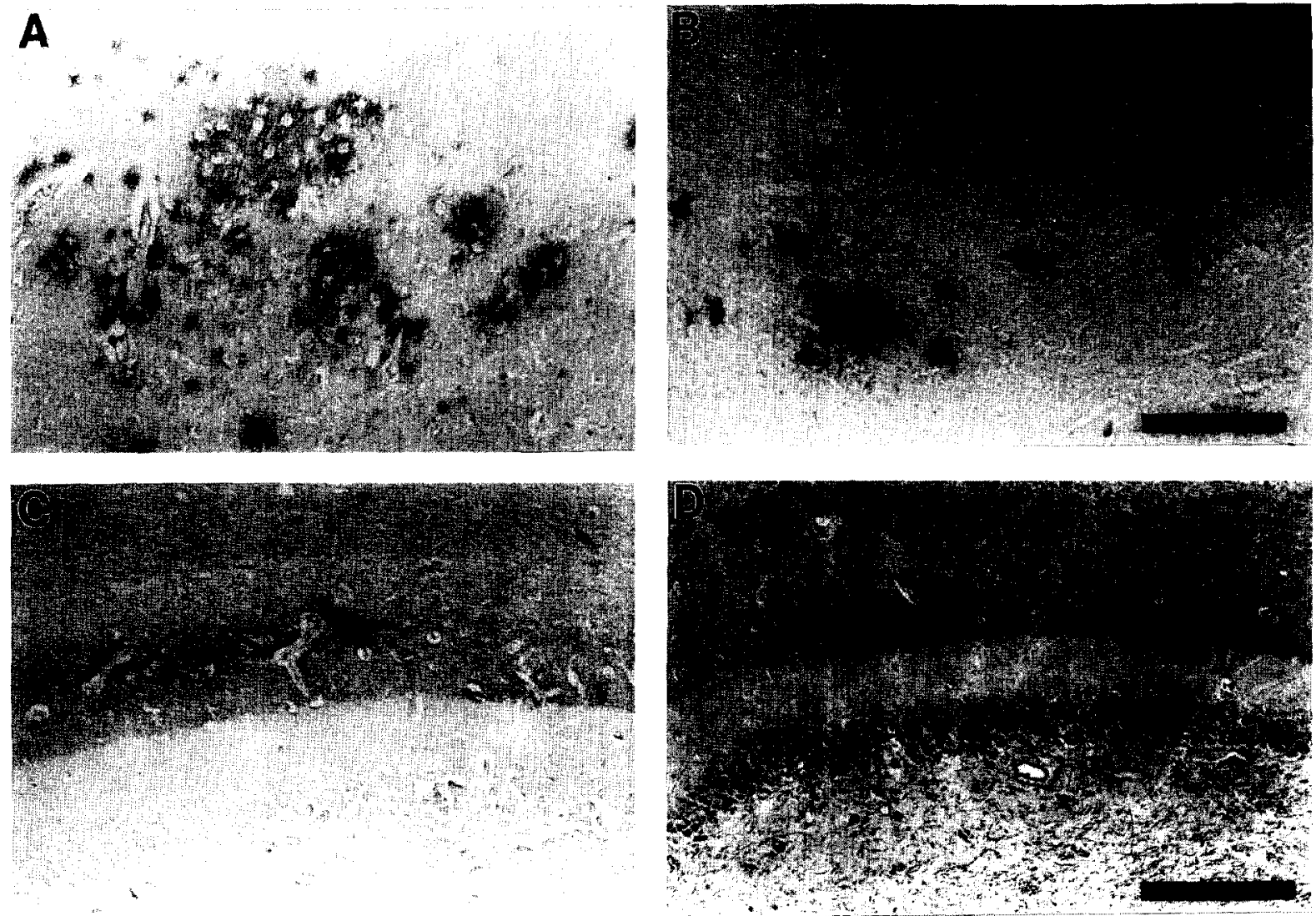

FIG. 6. $\beta$-Amyloid deposits in the aged beagle dog. The $7 \mathrm{~A} 3$ (anti-A 342 ) antibody immunostained diffuse plaques at the parahippocampal gyrus in an aged beagle dog (14.5 years of age, female) (A). These deposits were also labeled by 10D5 but not by anti-A $\beta 40$ (not shown). In contrast, vascular and perivascular amyloid deposits were immunolabeled with anti-AB40 (B). A cloud of $A \beta$ was evident throughout the outer molecular layer of the dentate gyrus. This cloud was immunostained with 7A3 (C), 10D5 (see Fig. 7), and with Bielschowsky silver stain (D). The scale bar in (B) $=100 \mu \mathrm{m}$, the scale bar shown in (D) $=200 \mu \mathrm{m}$ and also applies to (A) and (C).

1) illustrates that monoclonal antibody $7 \mathrm{~A} 3$ ascites recognizes $A \beta 1-42$ and $1-43$, but not the $A \beta 1-40$ sequence. The ascites was produced from the same clonal cell line used to produce the hybridoma supernatant. 7A3 ascites labels $A \beta 1-40$ only at antibody dilutions that also recognize $A \beta 1-28$. Since $A \beta 1-28$ has no overlap with the $A \beta 37-42$ used to generate the antibody, this represents background staining. At dilutions greater than $1: 400$, the ascites specifically recognizes $A \beta 42(43)$. The ELISA results, obtained using the hybridoma supernatant, verify the specificity of $7 \mathrm{~A} 3$ for $\mathrm{A} \beta 42$ (Fig. 2). The 7A3 hybridoma supernatant was used for immunocytochemistry at a dilution of $1: 20$. Preadsorption of 7A3 with $A \beta 37-42$ largely abolished immunostaining, although some plaques were very faintly stained (results not shown). Preadsorption of 10D5 and anti-A 340 with the same peptide did not alter the pattern of immunostaining. In contrast, 10D5 and antiA 340 immunostaining was greatly diminished following preadsorption with $A \beta 1-40$, but preadsorption with this peptide did not alter the results obtained with 7A3. Together, these results demonstrate the specificity of $7 \mathrm{~A} 3$ for $A \beta 42(43)$, anti- $A \beta 40$ for $A \beta 40$, and 10D5 for both $A \beta 40$ and $A \beta 42(43)$.

In both $A D$ subjects and nondemented individuals, the pattern of immunostaining obtained with 7A3 was similar to that obtained with the AB1-16 directed antibody 10D5 (Fig. 3). Both antibodies recognized the following morphological subtypes of $A \beta$ deposits: 1) diffuse deposits, $10-200 \mu \mathrm{m}$ in size, irregularly shaped, faintly immunostained; 2) primitive plaques, $20-60 \mu \mathrm{m}$, round, moderately stained, well demarcated; 3 ) mature (cored) plaques, which were similar to primitive plaques but had a distinct core and halo and were strongly immunostained; and 4) compact deposits, 5-15 $\mu \mathrm{m}$, no halo, strongly immunostained. The plaques in the nondemented subjects were mainly of the diffuse type, whereas numerous mature and compact deposits were evident in AD cases. In mature (cored) plaques, both the core and halo were immunostained with approximately equal intensity by the 10D5 antibody. In contrast, $7 \mathrm{~A} 3$ results were more variable, with the core being more strongly stained in some plaques and the halo in others (Fig. 3). 7A3 and 10D5 also recognized cerebrovascular amyloid deposits, which were particularly evident in some leptomeningeal vessels. A polyclonal antibody, highly selective for $A \beta 40$ (anti$A \beta 40)(20)$, recognized a subset of primitive mature and compact plaques, but did not immunostain diffuse plaques (Fig. 3). In mature plaques, the core was intensely labeled and the halo faintly immunostained. Cerebrovascular amyloid was strongly immunostained by anti-A $\beta 40$.

In two aged polar bears, many diffuse plaques were intensely immunostained with the 10D5 and 7A3 antibodies, but were not recognized by anti-A $\beta 40$ (Fig. 4). Consistent with prior observations, in both human and canine brains, diffuse deposits often surrounded several unstained areas that contained morphologically normal neuronal cell bodies $(2,8)$. Cerebrovascular amyloid was present in one of the animals (PB2) and deposits were immunoreactive with $10 \mathrm{D} 5,7 \mathrm{~A} 3$, and anti-A $\beta 40$. However, some deposits were strongly immunostained with $7 \mathrm{~A} 3$ and not with anti-A $\beta 40$ (Figs. 4 and 5). In each of the aged bears, PHF-1 antibody immu- 
nostained many neuronal perikarya and some apical dendrites, but infrequently labeled dystrophic plaque neurites and neuropil threads (Fig. 4). The presence of tangles, but lack of neuritic abnormalities, was also revealed with the Bielschowsky stain. Thioflavin $\mathrm{S}$ revealed cerebrovascular amyloid, but did not detect diffuse deposits.

Diffuse plaques, present in each of the aged dog brains, were immunostained with $10 \mathrm{D} 5$ and $7 \mathrm{~A} 3$, but not by anti-A $\beta 40$ (Fig. 6). These were faint and amorphous, in contrast to the more compacted $\beta$-amyloid diffuse deposits observed in the human and polar bear brain sections. The diffuse clouds were observed in cortical regions of each dog and in the outer molecular layer of the dentate gyrus in four of the five animals (Fig. 6). In two animals (D1 and D4), well-circumscribed parenchymal diffuse $\beta$-amyloid deposits were strongly immunostained with $7 \mathrm{~A} 3$ and $10 \mathrm{D} 5$, but faintly recognized by $A \beta 40$ (Fig. 6A). These resembled primitive plaques observed in the human brain, but were not associated with dystrophic neurites, as determined using PHF-1 immunocytochemistry and the Bielschowsky stain. Moreover, these deposits were not revealed with Thioflavin S. Cerebrovascular amyloid deposits were present in each of the aged dogs examined, and were immunostained by the 7A3, 10D5, and anti-A 340 antibodies (Figs. 5 and $6 B$ ).

$\beta$-Amyloid deposits were observed in the dentate gyrus outer molecular layer (but not the inner molecular layer) in each of the species examined and illustrate the species differences observed in this study (Fig. 7). Deposits appear as a diffuse cloud in the aged beagle dog brain, as more condensed deposits in the aged polar bear, and as mature cored and compact plaques in $\mathrm{AD}$. In some aged beagle dog brains, Bielschowsky stain has revealed $A \beta$ deposits in the dentate gyrus outer molecular layer, which resemble the more aggregated state observed in the aged polar bear [see (33)].

\section{DISCUSSION}

This study compared the C-terminus of $\beta$-amyloid deposits in aged beagles and polar bears with those in the aged normal, and AD human brain. In all three species, diffuse plaques were positively immunostained with an antibody (7A3) that recognizes $A \beta 42(43)$, but not $A \beta 40$. Polar bear and dog brain CVA contained both $A \beta 42(43)$ and $A \beta 40$. However, some CVA deposits in the polar bear were preferentially labeled by anti-A $\beta 42(43)$. Naslund and colleagues (27) have reported that $A \beta 42$ is the principal $A \beta$ variant present in nondemented elderly controls. Ihara and coworkers (14) and Cole and colleagues (20) have observed that all senile plaques are positively labeled with anti-42(43), while only a subset of these plaques are $A \beta 40$ immunopositive. Thus, the results of this study extend those previously reported in human brain and demonstrate that $A \beta 42(43)$ is the initially deposited isoform in diffuse plaques in several mammalian species. The results further suggest that $A \beta 42(43)$ is initially deposited in CVA.

Mature plaques, which contain $A \beta 40$, were not observed in the aged dog or polar bear. These plaques are thought to evolve from diffuse plaques, based on temporal events in the development of AD-like pathology in individuals with Down syndrome (22). A1ternatively, the formation of each plaque type may involve unique mechanisms, with CVA possibly contributing to neuritic plaques (38). In the aged mammals, the presence of CVA deposits and absence of neuritic plaques support distinctive plaque developmental mechanisms. In addition, the brain regions exhibiting CVA deposits were often spatially separated from diffuse plaques. Moreover, some animals had diffuse plaques without CVA, arguing against a relationship between the two lesions.

A polar bear (age 28), has previously been reported to have senile plaques, but not neurofibrillary tangles $(7,36)$. However, the
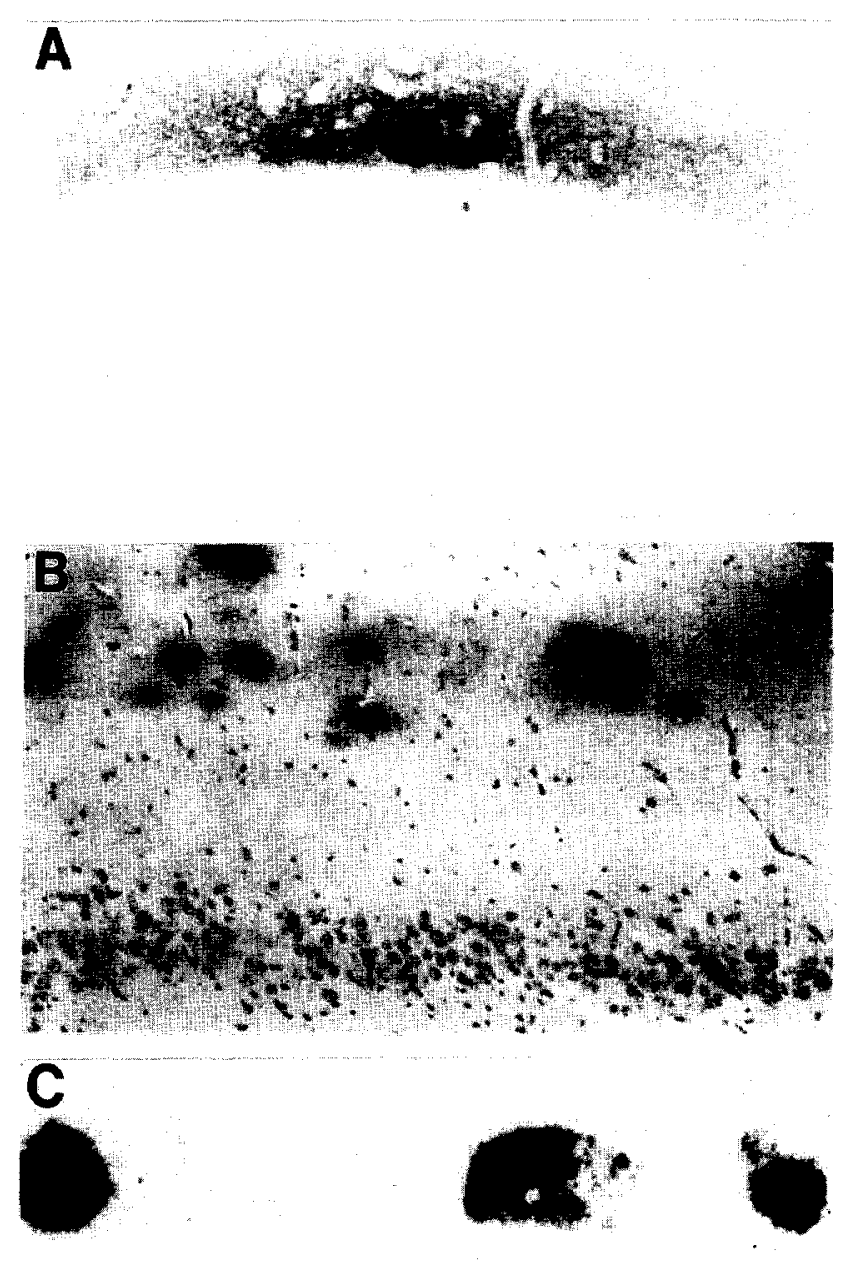

FIG. 7. $\beta$-Amyloid deposits in the dentate gyrus outer molecular layer of the dog, polar bear, and human brain. The 10D5 antibody immunolabeled $A \beta$ deposits in the dentate gyrus outer molecular layer in each species examined. In the $\operatorname{dog}(\mathrm{A}), A \beta$ was present as a faint diffuse cloud in the outer molecular layer. In the polar bear (B), the deposits were amorphous, although distinct plaques were apparent. This section was also stained with hematoxylin. In the brain of a nondemented, 84-year old, female welldefined $A \beta$ deposits were evident (C). In each case the plaques were also stained by the 7A3 antibody, but not by anti-A 340 (not shown). Scale bar $=200 \mu \mathrm{m}(\mathrm{C})$.

senile plaque designation was based upon neurites immunostained with an anti-neurofilament antibody. Plaque-associated neurites were not labeled by Alz-50, anti-paired helical filament, or anti-tau antibodies $(7,36)$. Neurofibrillary tangles, in the absence of senile plaques, have been observed in an Asiatic brown bear (7). The NFTs were immunoreactive with Alz-50, antibodies against phosphorylated neurofilament epitopes, and an antibody that recognizes PHFs and tau. Electron microscopy demonstrated that the tangles contained straight $10-16 \mathrm{~nm}$ filaments, but not paired helical filaments. In the present study, polar bear tangles were detected with 
both modified Bielschowsky silver stain and the PHF-1 antibody against phosphorylated tau. Plaque dystrophic neurites were not observed with either stain. The $A \beta$ deposits in the aged polar bear brain are, therefore, regarded as diffuse plaques.

Senile plaques have been reported in aged dogs $(38,39,49)$, whereas other studies suggest the plaques are entirely of the diffuse type $(3,8,11,33)$. Many of the senile plaque designations were described prior to diffuse plaque characterization. Reexamination of the reports suggests that these plaques are of the diffuse type. For example, in a study by Wisniewski and colleagues (49), the lack of a neuritic reaction to the amyloid deposits is noted. Additionally, Shimada's plaque characterization is solely based on $\beta$-amyloid immunostaining $(38,39)$. The mature plaque forms described by this group appear similar to vascular or perivascular $\beta$-amyloid deposits. The prevalence of diffuse plaques observed in this study, along with cerebrovascular $\beta$-amyloid deposits, is consistent with previous reports of amyloid deposition in aged dogs.

$A \beta$ deposits in the dentate gyrus outer molecular layer were observed in the aged dog, bear, and human brain. The neurons that project to this region are located in layer II of the entorhinal cortex and are the first to exhibit neurofibrillary pathology $(4,46)$. Although the relationship between the two lesions is unclear, the presence of $A \beta$ in the dentate gyrus outer molecular layer in the aged beagle dog brain, but lack of pathology in entorhinal cortex, illustrates that $A \beta$ deposition precedes (or occurs in the absence of) neurofibrillary pathology. The results further suggest that the dentate gyrus outer molecular layer is one of the earliest sites of $\mathrm{A} \beta$ deposition in the aged mammalian brain.

Although diffuse $A \beta$ deposits in the aged beagle dog, polar bear, and human brain are each labeled with antibodies against A $342(43)$, they are morphologically distinct. The deposits in the dog brain are faint and cloud-like, whereas those in the human brain are more compact and intensely immunostained. $A \beta$ deposits in the polar bear appear to represent an intermediate stage. Trans- genic mice overexpressing $\mathrm{V} 717 \mathrm{~F} \beta$-amyloid precursor protein exhibit $\beta$-amyloid deposits at the dentate gyrus outer molecular layer $(10)$, which resemble those observed in the polar bear. In both of these models, amyloid clouds and aggregates are apparent. The cause of the species differences is uncertain, but could reflect an age-related increase in $\beta$ APP expression, inability to clear extracellular $\beta$-amyloid, or species differences in the proteins associated with $A \beta$, which may promote $A \beta$ aggregation. $A \beta$ aggregation promoting factors include $\alpha$ l-antichymotrypsin (1), apolipoprotein E $(26,42)$, heparan sulfate proteoglycan $(40)$ and non$A \beta$ component (45). It is also possible that the differences reflect case-to-case variability among individual animals.

Overall, the processes involved in age-related $A \beta$ deposition appear to be similar among the examined mammalian species. The results obtained in the animal models closely resemble $A \beta$ deposition in the aged human brain and the early stages of Alzheimer pathology observed in individuals with Down syndrome; $A \beta 42(43)$ immunopositive diffuse plaques precede the appearance of $A \beta 40$ immunopositive mature plaques and neurofibrillary tangles. The results further suggest that diffuse plaques begin as a widespread deposit of $\beta$-amyloid that gradually coalesces into a more compact, spherical mass. In the aged beagle dog and aged polar bear, the lack of extensive $A D$ pathology suggests that $A \beta 42$ deposition may be necessary but not sufficient to trigger AD. The data illustrate that these aged mammals serve as useful models of the initial stages of $\beta$-amyloid deposition.

\section{ACKNOWLEDGEMENTS}

We thank Athena Neurosciences for the 10D5 antibody, Dr. Sharon Greenberg for the PHF-1 antibody, and Dr. Steven Estus for helpful discussions and comments on the manuscript. This work was supported by NIH Grants AG9009 and AGI125 (G.M.C.); AG10678 (J.W.G.); AG10678 (M.J.R.); AG05144 and AG05119 (W.R.M.); AG09862 and AG00553 (D.A.S.).

\section{REFERENCES}

1. Abraham, C. R.; Selkoe, D. J.; Potter, H. Immunochemical identification of the serine protease inhibitor $\alpha 1$-antichymotrypsin in the brain amyloid deposits of Alzheimer's disease. Cell 52:487-501; 1988.

2. Allsop, D.; Haga, S. I.; Haga, C.; Ikeda, S. I.; Mann, D. M.; Ishii, T. Early senile plaques in Down's syndrome brains show a close relationship with cell bodies of neurons. Neuropathol. Appl. Neurobiol. 15:531-542; 1989.

3. Ball, M. J.; MacGregor, J.; Fyfe, I. M.; Rapoport, S. I.; London, E. D. Paucity of morphological changes in the brains of ageing beagle dogs: Further evidence that Alzheimer lesions are unique for primate central nervous system. Neurobiol. Aging. 4:127-131; 1983.

4. Braak, H.; Braak, E. Neuropathological stageing of Alzheimer-related changes. Acta Neuropathol. (Berl.) 82:239-259; 1991.

5. Burdick, D.; Soreghan, B.; Kwon, M.; Kosmoski, J.; Knauer, M.; Henschen, A.; Yates, J.; Cotman, C.; Glabe, C. Assembly and aggregation properties of synthetic Alzheimer's A4/beta amyloid peptide analogs. J. Biol. Chem. 267:546-554; 1992.

6. Conn, K. J.; Papastoitsis, G.; Meckelein, B.; Abraham, C. R. Identification of full length $\beta$-amyloid precursor protein in human neuronal and nonneuronal cell culture supernatant: $A$ possible extracellular source for the generation of $A \beta$. Amyloid: Int. J. Clin. Invest. 1:232239; 1994.

7. Cork, L. C.; Powers, R. E.; Selkoe, D. J.; Davies, P.; Geyer, J. J.; Price, D. L. Neurofibrillary tangles and senile plaques in aged bears. J. Neuropathol. Exp. Neurol. 47:629-641; 1988.

8. Cummings, B. J.; Su, J. H.; Cotman, C. W.; White, R.; Russell, M. J Beta-amyloid accumulation in aged canine brain: A model of early plaque formation in Alzheimer's disease. Neurobiol. Aging 14:547$560 ; 1993$.

9. Dickson, D. W.; Crystal, H. A.; Mattiace, L. A.; Masur, D. M.; Blau, A. D.; Davies, P.; Yen, S. H.; Aronson, M. K. Identification of normal and pathologic aging in prospectively studied nondemented elderly humans. Neurobiol. Aging 13:179-189; 1992

10. Games, D.; Adams, D.; Alessandrini, R.; Barbour, R.; Berthelette, P.; Blackwell, C.; Carr, T.; Clemens, J.; Donaldson, T.; Gillespie, F.; Guido, T.; Hagopian, S.; Johnson-Wood, K.; Khan, K.; Lee, M.; Leibowitz, P.; Liebergurg, I.; Little, S.; Masliah, E.; McConlogue, L.; Montoya-Azvala, M.; Mucke, L.; Paganini, L.; Penniman, E.; Power, M.; Schenk, D.; Seubert, P.; Snyder, B.; Soriano, F.; Tan, H.; Vitale, J.; Wadsworth, S.; Wolozin, B.; Zhao, J. Alzheimer-type neuropathology in transgenic mice overexpressing V717F $\beta$-amyloid precursor protein. Nature 373:523-527; 1995.

11. Giaccone, G.; Verga, L.; Finazzi, M.; Pollo, B.; Tagliavini, F.; Frangione, B.; Bugiani, O. Cerebral preamyloid deposits and congophilic angiopathy in aged dogs. Neurosci. Lett. 114:178-183; 1990.

12. Greenberg, S. G.; Davies, P.; Schein, J. D.; Binder, L. I. Hydrofluoric acid-treated tau PHF proteins display the same biochemical properties as normal tau. J. Biol. Chem. 267:564-569; 1992.

13. Iwatsubo, T.; Mann, D. M. A.; Odaka, A.; Suzuki, N.; Ihara, Y. Amyloid $\beta$ protein $(A \beta)$ deposition: $A \beta 42(43)$ precedes $A \beta 40$ in Down syndrome. Ann. Neurol. 37:294-299; 1995.

14. Iwatsubo, T.; Odaka, A.; Suzuki, N.; Mizusawa, H.; Nukina, N.; Ihara, $Y$. Visualization of $A \beta 42(43)$ and $A \beta 40$ in senile plaques with endspecific $A \beta$ monoclonals: Evidence that an initially deposited species is $A \beta 42(43)$. Neuron $13: 45-64 ; 1994$.

15. Jarrett, J. T.; Berger, E. P.; Lansbury, P. T. J. The carboxy terminus of the $\beta$ amyloid protein is critical for the seeding of amyloid formation: Implications for the pathogenesis of Alzheimer's disease. Biochemistry 32:4693-4697; 1993.

16. Johnstone, E. M.; Chaney, M. O.; Norris, F. H.; Pascual, R.; Little, S. P. Conservation of the sequence of the Alzheimer's disease amyloid peptide in dog, polar bear and five other mammals by cross-species 
polymerase chain reaction analysis. Brain Res. Mol. Brain Res. 10: 299-305; 1991.

17. Khachaturian, Z, S. Diagnosis of Alzheimer's disease. Arch. Neurol. 42:1097-1105; 1985.

18. Kida, E.; Golabek, A. A.; Wisniewski, T.; Wisniewski, K. E. Regional differences in apolipoprotein $\mathrm{E}$ immunoreactivity in diffuse plaques in Alzheimer's disease brain. Neurosci. Lett. 167:73-76; 1994.

19. Kitamoto, T.; Ogomori, K.; Tateishi, J.; Prusiner, S. B. Formic acid pretreatment enhances immunostaining of cerebral and systemic amyloids. Lab. Invest. 57:230-236; 1987.

20. Mak, K.; Yang, F.; Vinters, H. V.; Frautschy, S. A.; Cole, G. M. Polyclonals to $\beta$-amyloid (1-42) identify most plaque and vascular deposits in Alzheimer cortex, but not striatum. Brain Res. 667:138-142; 1994.

21. Mandybur, T. I. The incidence of cerebral amyloid angiopathy in Alzheimer's disease. Neurology 25:120; 1975.

22. Mann, D. M.; Brown, A.; Prinja, D.; Davies, C. A.; Landon, M.; Masters, C. L.; Beyreuther, K. An analysis of the morphology of senile plaques in Down's syndrome patients of different ages using immunocytochemical and lectin histochemical techniques. Neuropathol Appl. Neurobiol. 15:317-329; 1989.

23. Martin, L. J.; Pardo, C. A.; Cork, L. C.; Price, D. L. Synaptic pathology and glial responses to neuronal injury precede the formation of senile plaques and amyloid deposits in the aging cerebral cortex. Am J. Pathol. 145:1358-1381: 1994

24. Miller, D. L.; Papayannopoulos, I. A.; Styles, J.; Bobin, S. A.; Lin, Y. Y.; Biemann, K.; Iqbal, K. Peptide compositions of the cerebrovascular and senile plaque core amyloid deposits of Alzheimer's disease. Arch. Biochem. Biophys. 301:41-52; 1993.

25. Mori, H.; Takio, K.; Ogawara, M.; Selkoe, D. J. Mass spectrometry of purified amyloid $\beta$ protein in Alzheimer's disease. J. Biol. Chem. 267:17082-17086; 1992.

26. Namba, Y.; Tomonaga, M.; Kawasaki, H.; Otomo, E.; Ikeda, K. Apolipoprotein $\mathrm{E}$ immunoreactivity in cerebral amyloid deposits and neurofibrillary tangles in Alzheimer's disease and kuru plaque amyloid in Creutzfeldt-Jakob disease. Brain Res. 541:163-166; 1991.

27. Näslund, J.; Schierhorn, A.; Hellman, U.; Lannfelt, L.; Roses, A. D.; Tjernberg, L. O.; Silberring, J.; Gandy, S. E.; Winblad, B.; Greengard, P.; Norstedt, C.; Terenius, L. Relative abundance of Alzheimer A beta amyloid peptide variants in Alzheimer disease and normal aging. Proc. Natl. Acad. Sci. USA 91:8378-8382; 1994.

28. Pike, C. J.; Burdick, D.; Walencewicz, A. J.; Glabe, C. G.; Cotman, C. W. Neurodegeneration induced by beta-amyloid peptides in vitro: The role of peptide assemtly state. J. Neurosci. 13:1676-1687; 1993

29. Pike, C. J.; Walencewicz, A. J.; Glabe, C. G.; Cotman, C. W. Aggregation-related toxicity of synthetic beta-amyloid protein in hippocampal cultures. Eur. J. Pharmacol. 207:367-368; 1991

30. Poduri, A.; Gearing, M.; Rebeck, G. W.; Mirra, S. S.; Tigges, J.; Hyman, B. T. Apolipoprotein E4 and beta amyloid in senile plaques and cerebral blood vessels of aged thesus monkeys. Am. J. Pathol. 144: 1183-1187; 1994.

31. Roher, A. E.; Lowenson, J. D.; Clarke, S.; Wolkow, C.; Wang, R. Cotter, R. J.; Reardon, I. M.; Zürcher-Neely, H. A.; Heinrikson, R. L.; Ball, M. J.; Greenberg, B. D. Structural alterations in the peptide backbone of $\beta$-amyloid core protein may account for its deposition and stability in Alzheimer's disease. J. Biol. Chem. 268:3072-3083; 1993.

32. Rozemuller, H. M.; Eikelenboom, P.; Stam, F. C.; Beyreuther, K.; Masters, C. L. A4 protein in Alzheimer's disease: Primary and secondary cellular events in extracellular amyloid depostion. J. Neuropathol. Exp. Neurol. 48:674-691; 1989

33. Russell, M. J.; White, R.; Pctel, E.; Markesbery, W. R.; Watson, C. R.; Geddes, J. W. Familial influence on plaque formation in the beagle brain. Neuroreport 3:1093-1096; 1992.

34. Saido, T. C.; Iwatsubo, T.; Mann, D. M. A.; Shimada, H.; Ihara, Y.; Kawashima, S. Dominant and differential deposition of distinct $\beta$-amyloid species, $A \beta N 3(p E)$, in senile plaques. Neuron 14:457-486; 1995.

35. Selkoe, D. J. Normal and abnormal biology of the beta-amyloid precursor protein. Annu. Rev. Neurosci. 17:489-517; 1994.

36. Selkoe, D. J.; Bell, D. S.; Podlisny, M. B.; Price, D. L.; Cork, L. C. Conservation of brain amyloid proteins in aged mammals and humans with Alzheimer's disease. Science 235:873-877; 1987.

37. Seubert, P.; Vigo, P. C.; Esch, F.; Lee, M.; Dovey, H.; Davis, D.; Sinha, S.; Schlossmacher, M.; Whaley, J.; Swindlehurst, C.; McCormack, R.; Wolfert, R.; Selkoe, D.; Ljeberburg, I.; Schenk, D. Isolation and quantification of soluble Alzheimer's $\beta$-peptide from biological fluids. Nature 359:325-327; 1992.

38. Shimada, A.; Kuwamura, M.; Awakura, T.; Umemura, T.; Takada, K.; Ohama, E.; Itakura, C. Topographic relationship between senile plaques and cerebrovascular amyloidosis in the brain of aged dogs. $\mathbf{J}$. Vet. Med. Sci. 54:137-144; 1992.

39. Shimada, A.; Kuwamura, M.; Umemura, T.; Takada, K.; Ohama, E.; Itakura, C. Modified Bielschowsky and immunohistochemical studies on senile plaques in aged dogs. Neurosci. Lett. 129:25-38; 1991.

40. Snow, A. D.; Mar, H.; Nochlin, D.; Kimata, K.; Kato, M.; Suzuki, S.; Hassell, J.; Wight, T. N. The presence of heparan sulfate proteoglycans in the neuritic plaques and congophilic angiopathy in Alzheimer's disease. Am. J. Pathol. 133:456-463; 1988.

41. Soto, C.; Branes, M. C.; Alvarez, J.; Inestrosa, N. C. Structural determinants of the Alzheimer's amyloid beta-peptide. J. Neurochem. 63: 1191-1198; 1994.

42. Strittmatter, W. J.; Saunders, A. M.; Schechel, D.; Pericak-Vance, M.; Enghild, J.; Salvesen, G. S.; Roses, A. D. Apoliprotein E: High-avidity binding to $\beta$-amyloid and increased frequency of type 4 allele in late-onset familial Alzheimer disease. Proc. Natl. Acad. Sci. USA 90:1977-1981; 1993

43. Suzuki, N.; Cheung, T. T.; Cai, X. D.; Odaka, A.; Otvos, L. J.; Eckman, C.; Golde, T. E.; Younkin, S. G. An increased percentage of long amyloid $\beta$ protein secreted by familial amyloid $\beta$ protein precursor (BAPP717) mutants. Science 264:1336-1340; 1994.

44. Tomlinson, B. E.; Blessed, G.; Roth, M. Observations on the brains of nondemented old people. J. Neurol Sci. 7:331-356; 1968.

45. Uéda, K.; Fukushima, H.; Masliah, E.; Xia, Y.; Iwai, A.; Yoshimoto, M.; Otero, D. A. C.; Kondo, J.; Ihara, Y.; Saitoh, T. Molecular cloning of a novel component of amyloid in Alzheimer's disease. Proc. Natl. Acad. Sci. USA 90:11282-11286; 1993.

46. Van Hoesen, G. W.; Hyman, B. T. Hippocampal formation: Anatomy and the patterns of pathology in Alzheimer's disease. In: StormMathisen, J.; Zimmer, J; Ottersen, O. P., eds. Progress in brain research. New York: Elsevier; 1990.

47. Vinters, H. V. Cerebral amyloid angiopathy and Alzheimer's disease: Two entities or one? J. Neurol Sci. 112:1-3; 1992.

48. Walker, L. C.; Price, D. L.; Voytko, M. L.; Schenk, D. B. Labeling of cerebral amyloid in vivo with a monoclonal antibody. J. Neuropathol. Exp. Neurol. 53:377-383; 1994.

49. Wisniewski, H.; Johnson, A. B.; Raine, C. S.; Kay, W. J.; Terry, R. D. Senile plaques and cerebral amyloidosis in aged dogs. A histochemical and ultrastructural study. Lab. Invest. 23:287-296; 1970.

50. Wisniewski, H. M.; Terry, M. D. Reexamination of the pathogenesis of the senile plaque. In:Zimmerman, H. M., ed. Progress in Neuropathology. New York, NY: Grune \& Stratton, Inc; 1973;1-26.

51. Yamamoto, T.; Hirano, A. A comparative study of modified Bielschowsky, Bodian and thioflavin S stains on Alzheimer's neurofibrillary tangles. Neuropathol. Appl. Neurobiol. 12:3-9; 1986.

52. Yang, F.; Mak, K.; Vinters, H. V.; Frautschy, S. A.; Cole, G. M. Monoclonal antibody to the $C$-terminus of $\beta$-amyloid. Neuroreport $5: 2117-2120 ; 1994$

53. Younkin, S. G. Evidence that $A \beta 42$ is the real culprit in Alzheimer's Disease. Ann. Neurol. 37:287-288; 1995. 